\title{
Activation of somatostatin 2 receptors in the brain and the periphery induces opposite changes in circulating ghrelin levels: functional implications
}

\section{Andreas Stengel ${ }^{1}$ * and Yvette Taché ${ }^{2}$ *}

${ }^{1}$ Division Psychosomatic Medicine and Psychotherapy, Department of Medicine, Obesity Center Berlin, Charité, Universitätsmedizin Berlin, Berlin, Germany 2 Digestive Diseases Division, CURE: Digestive Diseases Research Center, Center for Neurobiology of Stress and Women's Health, Department of Medicine, VA Greater Los Angeles Health Care System, University of California at Los Angeles, Los Angeles, CA, USA

\author{
Edited by: \\ Hubert Vaudry, University of Rouen, \\ France

\section{Reviewed by:} \\ Rafael Vazquez-Martinez, University of \\ Cordoba, Spain \\ Francisco Gracia-Navarro, University \\ of Cordoba, Spain

\section{*Correspondence:} \\ Andreas Stengel, Division \\ Psychosomatic Medicine and \\ Psychotherapy, Department of \\ Medicine, Obesity Center Berlin, \\ Charité, Universitätsmedizin Berlin, \\ Luisenstr. 13a, 10117 Berlin, Germany. \\ e-mail: andreas.stengel@charite.de; \\ Yvette Taché, Digestive Diseases \\ Division, CURE: Digestive Diseases \\ Research Center, Center for \\ Neurobiology of Stress and Women's \\ Health, Department of Medicine, VA \\ Greater Los Angeles Health Care \\ System, University of California at Los \\ Angeles, CURE Building 115, Room \\ 117, 11301 Wilshire Boulevard, \\ Los Angeles, CA 90073, USA. \\ e-mail:ytache@mednet.ucla.edu
}

Somatostatin is an important modulator of neurotransmission in the central nervous system and acts as a potent inhibitor of hormone and exocrine secretion and regulator of cell proliferation in the periphery. These pleiotropic actions occur through interaction with five $\mathrm{G}$ protein-coupled somatostatin receptor subtypes $\left(s s_{1-5}\right)$ that are widely expressed in the brain and peripheral organs. The characterization of somatostatin's effects can be investigated by pharmacological or genetic approaches using newly developed selective sst agonists and antagonists and mice lacking specific sst subtypes. Recent evidence points toward a divergent action of somatostatin in the brain and in the periphery to regulate circulating levels of ghrelin, an orexigenic hormone produced by the endocrine X/A-like cells in the rat gastric mucosa. Somatostatin interacts with the sst $_{2}$ in the brain to induce an increase in basal ghrelin plasma levels and counteracts the visceral stress-related decrease in circulating ghrelin. By contrast, stimulation of peripheral somatostatin-sst, 2 signaling results in the inhibition of basal ghrelin release and mediates the postoperative decrease in circulating ghrelin. The peripheral $\mathrm{sst}_{2}$-mediated reduction of plasma ghrelin is likely to involve a paracrine action of $\mathrm{D}$ cell-derived somatostatin acting on $\mathrm{sst}_{2}$ bearing X/Alike ghrelin cells in the gastric mucosa. The other member of the somatostatin family, named cortistatin, in addition to binding to $\mathrm{sst}_{1-5}$ also directly interacts with the ghrelin receptor and therefore may simultaneously modulate ghrelin release and actions at target sites bearing ghrelin receptors representing a link between the ghrelin and somatostatin systems.

Keywords: X/A-like cell, somatostatin receptor subtypes, ghrelin cell, somatostatin receptor agonists and antagonist, cortistatin

\section{INTRODUCTION}

In 1972, Guillemin's group - while searching for additional releasing factors in hypothalamic extracts after their identification of thyrotropin-releasing hormone (TRH) - identified a novel negative regulator of pituitary somatotropic cells releasing growth hormone (GH; Brazeau et al., 1973). The cyclo peptide was named somatostatin (somatotropin release-inhibiting factor, SRIF), in keeping with its hypophysiotropic action (Guillemin, 2011). Somatostatin was found to be expressed in two biologically active isoforms: the tetradecapeptide somatostatin-14 (Brazeau etal., 1973) and the amino terminally extended octacosapeptide somatostatin- 28 generated by differential post-translational processing from a common precursor molecule (Pradayrol et al., 1980). Thereafter, a flow of articles in rodents and humans established the ubiquitous distribution of somatostatin in various brain areas (Finley et al., 1981; Johansson et al., 1984; Uhl et al., 1985) and peripheral organs including the gastrointestinal tract (Costa et al., 1977; Walsh, 1994). This was followed by the identification and characterization of five distinct, high-affinity, specific somatostatin receptors (sst) encoded by five distinct genes (Gahete et al., 2010a). Structurally, these receptors belong to the so-called "superfamily" of membrane G protein-coupled (GPC) receptors. The sst $_{1-5}$ have distinct as well as overlapping patterns of distribution in the brain (Fehlmann et al., 2000; Spary et al., 2008) and gut (Schafer and Meyerhof, 1999; Ludvigsen et al., 2004; Corleto et al., 2006) with a prominent expression of $s_{2} t_{2}$ in the gastrointestinal tract (Sternini etal., 1997). Studies using new pharmacological tools, namely selective sst subtype agonists and antagonists (Grace et al., 2006; Cescato et al., 2008; Erchegyi et al., 2008, 2009; Table 1) point toward the role of different $s t_{1-5}$ in mediating the large spectrum of somatostatin biological actions, mostly inhibitory in nature. Multiple effects of somatostatin can also result from the ability of sst to form both homodimers or heterodimers (sst 5 with sst $_{1}$ or dopamine $\mathrm{D}_{2}$ receptor, $s_{2 \mathrm{a}}$ with $\mathrm{sst}_{3}, \mathrm{D}_{2}$ or $\mu$ opioid receptor subtype 1) resulting in the activation of different intracellular signaling cascades (Rocheville et al., 2000; Baragli et al., 2007; Siehler et al., 2008).

Of interest to neuroendocrinologists, somatostatin's inhibitory action on pituitary GH release was soon extended to a wide range of hypophyseal hormones including prolactin, thyrotropin (thyroid-stimulating hormone, TSH), and adrenocorticotropic hormone (ACTH; Brown etal., 1984; Bertherat et al., 1995; 
Table 1 | Structure and receptor binding affinity of somatostatin and somatostatin receptor agonists.

\begin{tabular}{|c|c|c|c|c|c|c|}
\hline \multirow[t]{2}{*}{ Peptide } & \multirow[t]{2}{*}{ Structure } & \multicolumn{5}{|c|}{ Receptor binding affinity $\left(\mathrm{IC}_{50}, \mathrm{nM}\right)^{\mathrm{a}}$} \\
\hline & & sst $_{1}$ & sst $_{2}$ & sst $_{3}$ & sst $_{4}$ & sst $_{5}$ \\
\hline $\begin{array}{l}\text { Somatostatin-28 } \\
\text { Niollet et al., 1995) }\end{array}$ & $\begin{array}{l}\text { Ser-Ala-Asn-Ser-Asn-Pro-Ala-Met-Ala-Pro-Arg-Glu-Arg- } \\
\text { Lys-Ala-Gly-c[Cys-Lys-Asn-Phe-Phe-Trp-Lys-Thr-Phe- } \\
\text { Thr-Ser-Cys]-OH }\end{array}$ & $0.1-4.7$ & $0.4-5.2$ & 0.2 & $0.3-1.1$ & $0.05-0.19$ \\
\hline $\begin{array}{l}\text { Octreotide } \\
\text { (Grace etal., 2008) }\end{array}$ & 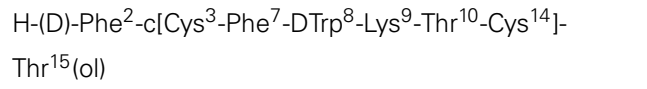 & $>1 \mathrm{~K}$ & $1.9 \pm 0.3$ & $39 \pm 14$ & $>1 \mathrm{~K}$ & $5.1 \pm 1.1$ \\
\hline $\begin{array}{l}\text { ODT8-SST } \\
\text { (Erchegyi et al., 2008) }\end{array}$ & des-AA $\left.{ }^{1,2,4,5,12,13-(D T r p}{ }^{8}\right)$-SST & $27.0 \pm 3.4$ & $41.0 \pm 8.7$ & $13.0 \pm 3.2$ & $1.8 \pm 0.7$ & $46.0 \pm 27.0$ \\
\hline $\begin{array}{l}\text { sst }_{2} \text { agonist } \\
\text { (Grace etal., 2006) }\end{array}$ & $\begin{array}{l}\left.\text { des-AA }{ }^{1,4-6,11-13} \text {-[DPhe }{ }^{2}, \mathrm{Aph}^{7}(\mathrm{Cbm}), \mathrm{DTrp}^{8}\right]-\mathrm{Cbm}- \\
\text { SST-Thr-NH}{ }_{2}\end{array}$ & $>1 \mathrm{~K}$ & $7.5-20$ & $942-1094$ & $872-957$ & $109-260$ \\
\hline $\begin{array}{l}\text { sst }_{2} \text { antagonist } \\
\text { (Cescato et al., 2008) }\end{array}$ & 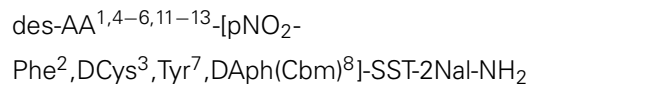 & $>1 \mathrm{~K}$ & $2.6 \pm 0.7$ & $384.0 \pm 97.0$ & $>1 \mathrm{~K}$ & $>1 \mathrm{~K}$ \\
\hline
\end{tabular}

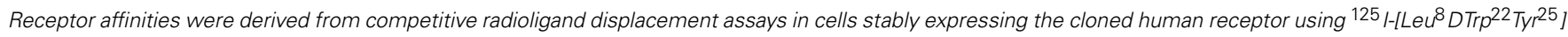

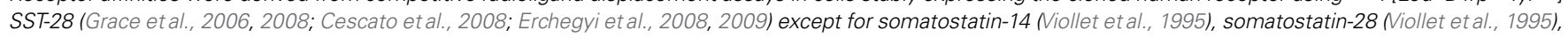
and cortistatin (Fukusumi etal., 1997).

Shimon et al., 1997) as well as a large number of hormones secreted from endocrine cells of the gastrointestinal tract including gastrin (Lloyd et al., 1997), cholecystokinin (CCK; Shiratori et al., 1991), secretin (Shiratori et al., 1991), gastric inhibitory peptide (GIP; Pederson et al., 1975), and neurotensin (Rokaeus, 1984), and from the pancreas glucagon (Marco et al., 1983; Strowski et al., 2000), insulin (Pederson et al., 1975; Marco et al., 1983; Strowski et al., 2000), and pancreatic polypeptide (PP; Marco et al., 1983). Studies to characterize the somatostatin receptor subtypes established that $s_{2} t_{2}$ is primarily involved and, to a smaller extent, sst $_{5}$ in the broad inhibitory effects of somatostatin on endocrine secretion (Lloyd et al., 1997; Strowski et al., 2000; de Heer et al., 2008). Of clinical relevance was also the compelling evidence that the majority of neuroendocrine tumors (NETs) expressed increased levels of sst $_{2}$ leading to the development of radiolabeled peptides and peptide receptor radionuclides as diagnostic and therapeutic tools respectively for NETs (van der Hoek et al., 2010; Culler et al., 2011; Giovacchini et al., 2012; Jawiarczyk et al., 2012).

In the past decade, a significant breakthrough came from the identification of a 28-amino-acid octanoylated peptide, ghrelin in the endocrine cells of the gastric mucosa as the cognate ligand for the $\mathrm{GH}$-secretagogue receptor 1a (GHS-R la $_{\text {a }}$, later renamed ghrelin receptor, GRLN-R; Kojima et al., 2001; Davenport et al., 2005). Ghrelin's interaction with the GRLN-R represents a third independent regulatory pathway controlling the pulsatile release of pituitary $\mathrm{GH}$ besides the GH-releasing hormone (GHRH) and somatostatin (Kojima et al., 2001; Malagon et al., 2003; Kineman and Luque, 2007).

Consistent with ghrelin, being predominantly produced by the endocrine cells of the stomach (Ariyasu et al., 2001), recent studies also documented that gastrointestinal NETs released ghrelin (Corbetta et al., 2003; Tsolakis et al., 2004). Therefore the regulation of ghrelin release by somatostatin will be of clinical relevance. The present review focuses on recent evidence that somatostatin signaling in the brain and the periphery exerts opposite influence on circulating ghrelin levels. The sst receptor subtype(s) involved and functional relevance of somatostatin-induced altered ghrelin plasma levels in the context of orexigenic and gastric prokinetic actions of the peptide (Kojima and Kangawa, 2005) will also be addressed.

\section{SOMATOSTATIN AND ITS RECEPTORS: EXPRESSION AND MODULATION OF FEEDING BEHAVIOR AND GASTROINTESTINAL MOTILITY EXPRESSION OF SOMATOSTATIN AND sst}

Somatostatin is expressed throughout the brain except in the cerebellum (Finley et al., 1981; Johansson et al., 1984). Peptide distribution has been investigated by immunohistochemistry indicating the expression in the cortex, limbic system, central nucleus of the amygdala, sensory structures, hypothalamus (including the arcuate, ventromedial, and paraventricular nucleus), and the periaqueductal central gray (Finley et al., 1981; Johansson et al., 1984; Moga and Gray, 1985). Similarly, sst receptor mRNA expression 
is widely detected in the rat brain including the deep layers of the cerebral cortex, bed nucleus of the stria terminalis, basolateral amygdaloid nucleus, medial amygdaloid nucleus, paraventricular thalamic nucleus, medial preoptic nucleus, dorsomedial and ventromedial hypothalamic nucleus, arcuate and paraventricular nucleus of the hypothalamus, substantia nigra, dorsal raphe nucleus, granular layer of the cerebellum, locus coeruleus, nucleus of the solitary tract, and the dorsal motor nucleus of the vagus nerve (Fehlmann et al., 2000; Spary et al., 2008). The wide distribution of the ligand along with the receptors is consistent with the pleiotropic action of the sst signaling systems.

Somatostatin is widely expressed in the gastrointestinal tract and the pancreas, namely in endocrine mucosal D cells scattered within the stomach, small and large intestine, and in $\delta$-cells of the pancreatic islets of Langerhans (Walsh, 1994). In addition, somatostatin is also detected in neurons of the gut enteric nervous system within both the submucosal and myenteric plexus (Costa et al., 1977). Similar to the ligand, sst receptor subtypes are widely expressed in the gastrointestinal tract. In rats, mRNA expression of $s t_{1}, s s t_{2}, s s t_{3}$, and $s_{4} t_{4}$ is detected in the small and large intestine without any clear predominance to one segment (Schafer and Meyerhof, 1999). The $s t_{1}$ is the predominant form in gastrointestinal tract of mice, whereas the sst $_{5}$ was almost undetectable (Schafer and Meyerhof, 1999). In human colon, a differential expression has been reported with $\mathrm{sst}_{2}$ mRNA expression on circular smooth muscle cells and $s t_{1-3}$ mRNA on longitudinal muscle layer cells (Corleto et al., 2006). Interestingly, in the pancreas protein expression of all $s t_{1-5}$ receptor subtypes has been identified on every major endocrine cell type, namely $\alpha, \beta, \delta$, and PP cells with a differential expression pattern between species (Ludvigsen et al., 2004).

\section{BRAIN ACTIONS OF SOMATOSTATIN}

The first function assigned to somatostatin was the inhibition of GH release (Brazeau et al., 1973). Now somatostatin is recognized to exert several central extrapituitary actions such as the regulation of other pituitary endocrine hormones especially those responsive to stress, parasympathetic and sympathetic outflow, thermogenesis, visceral functions, and behaviors. Namely, intracerebroventricular (icv) injection of somatostatin-28 inhibited the tail suspension stress-induced rise of circulating ACTH (Brown etal., 1984). This effect was mimicked by the stable pan-somatostatin agonist, ODT8-SST but not by somatostatin14 (Brown etal., 1984). The sst $_{2}$ seems to play a pivotal role in these regulatory processes as $s_{2} t_{2}$ receptor knockout mice display an increased ACTH release compared to their wild type littermates (Viollet et al., 2000).

With regard to the central actions of somatostatin to affect visceral functions, recent studies have focused on the gastrointestinal tract. ODT8-SST injected intracisternally (ic) in rats accelerated gastric emptying of a liquid non-nutrient solution. This effect is mimicked by somatostatin-28 and the sst $_{5}$ preferring agonist, BIM-23052 but not somatostatin-14 or the agonists preferring sst $_{1}$, CH-275, sst 2 , DC-32-87, sst 3 , BIM-23056, and sst 4 , L-803,087 (Martinez et al., 2000) indicating a prominent role of brain sst ${ }_{5}$ activation to induce a gastroprokinetic effect. This contention is further corroborated by the prominent mRNA expression of sst $_{5}$ in the dorsal motor nucleus of the vagus nerve (Thoss et al., 1995). Since sst receptors are also expressed in hypothalamic brain nuclei regulating colonic functions (Mönnikes et al., 1993; Mönnikes et al., 1994; Tebbe et al., 2005) including the arcuate ( sst $_{1-5}$; Fehlmann etal., 2000; Schulz etal., 2000) and paraventricular nucleus of the hypothalamus ( sst $_{2-4}$; Fehlmann et al., 2000; Schulz et al., 2000) and the locus coeruleus ( sst $_{2-4}$; Fehlmann et al., 2000; Schulz et al., 2000), several studies investigated whether activation of central somatostatin signaling influences colonic motor functions. Stressing mice by short exposure to anesthesia vapor and icv injection of vehicle robustly stimulated propulsive colonic motor function shown by a $99 \%$ increase in fecal pellet output (Stengel et al., 2011a). This effect was completely abolished by icv pretreatment with ODT8-SST, somatostatin-28 and the selective sst ${ }_{1}$ agonist, whereas $s_{2}$ or $_{2}$ st $_{4}$ agonists or octreotide (Table 1) had no effect. These data suggest that activation of brain sst $_{1}$ can prevent the stress-related stimulation of colonic propulsive motor function in mice (Stengel et al., 2011a).

Central somatostatin alters food intake with a divergent action depending on the doses used: an increase is induced by icv injection of lower (picomolar) doses and a decrease following high (nanomolar) in rats (Feifel and Vaccarino, 1990). The stable pan-somatostatin agonist, ODT8-SST (Erchegyi et al., 2008) icv stimulated food intake in rats under basal as well as already stimulated conditions during the dark phase with a rapid onset (during the first hour) and a long duration of action (lasting for $4 \mathrm{~h}$; Stengel et al., 2010a). ODT8-SST's orexigenic action is sst 2 mediated as it is reproduced by icv injection of the selective peptide $s^{2} t_{2}$ agonist (Stengel et al., 2010d) and blocked by the selective peptide $s t_{2}$ antagonist (Stengel et al., 2010a). This represents a central action since injected intraperitoneally at a 30 -fold higher dose, the peptide did not influence food intake (Stengel et al., 2010d). The orexigenic effect of central $s^{2} t_{2}$ stimulation observed in rats has been recently expanded to mice (Stengel et al., 2010c). A detailed analysis of the food intake microstructure using an automated food intake monitoring device showed that icv injection of the sst $_{2}$ agonist increased the number of meals, shortened inter-meal intervals, and induced a higher rate of ingestion, whereas meal sizes were not altered (Stengel et al., 2010c). Collectively, these data indicate that brain activation of $s_{2} t_{2}$ signaling pathways in rodents induces a rapid orexigenic response by decreasing satiety (number of meals), without influencing satiation indicated by normal meal sizes (Stengel et al., 2010c). The physiological role of brain $s_{2} t_{2}$ signaling in modulating food intake is also supported by the decrease of nocturnal food intake induced by the peptide sst $_{2}$ antagonist injected icv at the beginning of the dark phase (Stengel et al., 2010d). In addition, hypothalamic somatostatin shows a circadian rhythm with a peak in the early dark phase and a nadir in the early light phase (Gardi et al., 1999). Moreover, food restriction increases pituitary somatostatin release (Ishikawa et al., 1997) which could increase the drive to eat under these conditions.

\section{PERIPHERAL ACTIONS OF SOMATOSTATIN}

Contrasting to the central effects, somatostatin's actions in the periphery are largely inhibitory. In the stomach, somatostatin delays emptying of the food (Smedh et al., 1999) and inhibits 
gastric acid secretion which is mediated directly by an interaction with acid producing parietal cells but also via the reduced release of histamine from ECL cells and gastrin from G cells (Walsh, 1994). The acid-antisecretory action of somatostatin is no longer observed in $s^{2} t_{2}$ knockout mice, indicative of a primary role of the $s_{2} t_{2}$ (Piqueras et al., 2003). Similarly, in the small intestine somatostatin reduces intestinal peristalsis in cats, rabbits and rats, while stimulating the duodenal, jejunal, and ileal contractile response in dogs (Tansy et al., 1979). In line with the findings in rodents, somatostatin increases gastrointestinal transit time in humans (Gregersen et al., 2011). The effects on colonic motility are likely mediated by the $s_{1} t_{1}$ and $s_{2} t_{2}$ based on in vitro studies using circular and longitudinal human colonic smooth muscle cells (Corleto et al., 2006). In addition, somatostatin reduces visceral sensitivity with the $s_{2} t_{2}$ playing a key role as indicated by visceral hypersensitivity to both mechanical and chemical stimulation in the jejunum of sst $_{2}$ knockout mice (Rong et al., 2007). This finding is likely to be relevant in humans as well. Patients with irritable bowel syndrome injected subcutaneously with octreotide display an anti-hyperalgesic response as shown by the increased threshold of discomfort and pain using rectal barostat manometry compared to injection of placebo (Bradette et al., 1994; Schwetz et al., 2004).

\section{GHRELIN AND ITS RECEPTOR: EXPRESSION AND PHYSIOLOGICAL OREXIGENIC AND PROKINETIC ACTIONS EXPRESSION AND REGULATION OF GHRELIN AND GHRELIN RECEPTOR}

Ghrelin bears a unique fatty acid ( $n$-octanoyl) residue on the third amino acid which is essential for affinity and binding to the GRLN-R (Kojima et al., 1999; Kojima and Kangawa, 2005). Other dietary fatty acids of medium length can also serve as a direct source for the acylation of ghrelin (Nishi et al., 2005). The enzyme catalyzing the acylation of ghrelin was unknown for several years and just recently identified in mouse and human as a member of the membrane-bound $\mathrm{O}$-acyltransferases (MBOATs), namely MBOAT4 which was subsequently renamed ghrelin-Oacyltransferase (GOAT; Gutierrez et al., 2008; Yang et al., 2008). GOAT mRNA and protein are prominently expressed in rodent and human gastric mucosa in ghrelin expressing cells (Sakata et al., 2009; Stengel et al., 2010f). In addition, GOAT protein has been detected in rodent and human intestine, pancreatic duct, gallbladder, hypothalamus and pituitary gland (Gahete et al., 2010b; Lim et al., 2011; Kang et al., 2012), rodent plasma (Stengel et al., 2010f) and human visceral and subcutaneous adipocytes (Rodriguez et al., 2012) leading to the speculation of additional acylation sites of ghrelin.

Unlike ghrelin, desacyl ghrelin, which does not bear the hydrophobic residue on the third amino acid, is the main circulating form. The acyl:desacyl ghrelin ratio is 1:3 as recently reported using an optimized blood processing protocol to improve the yield of acylated ghrelin in rats (Stengel et al., 2009). Although desacyl ghrelin does not bind to and activate the GRLN-R (Kojima et al., 1999), recent studies indicate that the peptide exerts several biological actions to influence food intake (Stengel et al., 2010e), reduce inflammatory somatic pain (Sibilia et al., 2012), muscle cachexia produced by injury in rats (Sheriff et al., 2012) and basal autophagy in human visceral adipocytes (Rodriguez et al., 2012). However, the understanding of the physiological function of this peptide is hampered by the fact that the desacyl ghrelin receptor mediating its effects is still to be identified.

Blood levels of ghrelin vary in relation with the meal pattern with an increase before meals and a decrease thereafter (Cummings et al., 2001; Tschöp et al., 2001a). In addition, fasting also increases ghrelin mRNA expression (Toshinai et al., 2001; Kim et al., 2003; Xu et al., 2009) and reduces ghrelin peptide content in the stomach (Toshinai et al., 2001; Kim et al., 2003) indicative of a stimulated production and release under conditions of food deprivation. Ghrelin levels are not only regulated by shortterm variations in energy status associated with meal patterns but also by long-term changes in body weight. Ghrelin plasma levels are elevated under conditions of reduced body weight such as anorexia nervosa or tumor cachexia and reduced in obesity (Tschöp et al., 2000, 2001b; Cummings et al., 2002). Similar to the ligand, the ghrelin acylating enzyme, GOAT is regulated by the metabolic status with an increased GOAT mRNA and protein expression in rodent gastric mucosa, hypothalamus, and pituitary following a 12- or 24-h fast (Gonzalez et al., 2008; Gahete et al., 2010b; Stengel et al., 2010f). Under conditions of obesity induced by high fat diet or leptin deficiency in $o b / o b$ mice, a down-regulation of GOAT mRNA occurred in the mouse pituitary, unlike the stomach or hypothalamus (Gahete et al., 2010b), while patients with obesity-associated type 2 diabetes showed higher levels of GOAT in visceral adipose tissue (Rodriguez et al., 2012). This indicates a tissue specific regulation of GOAT under conditions of obesity.

\section{OREXIGENIC AND PROKINETIC EFFECTS OF GHRELIN}

Ghrelin is well established to stimulate food intake in line with its regulation by changes in energy status in many species including humans (Wren et al., 2000; Tang-Christensen et al., 2004; Druce et al., 2005). It is so far the only known peripherally produced and centrally acting orexigenic peptide, contrasting with the numerous anorexigenic peptides in the gut (Suzuki et al., 2011). Ghrelin's action is blocked by pharmacological or genetic approaches using GRLN-R antagonists (Salome et al., 2009) and GRLN-R knockout mice (Sun et al., 2004; Zigman et al., 2005) indicating a key role of ghrelin-GRLN-R interaction in mediating the orexigenic response. The food intake stimulatory action can result from ghrelin crossing the blood-brain barrier and binding to GRLN-R expressed on food intake regulatory brain nuclei (Banks et al., 2002; Pan et al., 2006) or acting directly on vagal afferents which also bear the ghrelin receptor (Date et al., 2002; Sakata et al., 2003). The respective role of these pathways under nutritional changes is still to be delineated. In addition to the stimulation of food intake, ghrelin is also involved in the regulation of body weight inducing an increase of body weight following chronic infusion of the peptide. This occurs through combined actions of stimulating appetite along with increasing fat storage and reducing lipid mobilization (Tschöp et al., 2000; Strassburg et al., 2008; Davies et al., 2009). Further corroborating these findings, ghrelin and GRLN-R double knockout mice display an increased energy expenditure leading to a reduction of body weight (Pfluger et al., 2008) which, however, could not be reproduced with a single genetic deletion of 
either ghrelin (Sun et al., 2003; Pfluger et al., 2008) or the GRLN$\mathrm{R}$ (Pfluger et al., 2008). These differential phenotypes may reflect the functional relevance of the high constitutive activity of the GRLN-R (Damian et al., 2012) and also give rise to the speculation that additional ligands for the receptor may exist (Deghenghi et al., 2001a).

\section{DIFFERENTIAL MODULATION OF GH RELEASE BY GHRELIN AND SOMATOSTATIN}

Ghrelin exerts endocrine actions opposite to somatostatin by stimulating anterior pituitary release of GH (Kojima et al., 1999; Yamazaki etal., 2002; Kojima and Kangawa, 2011), prolactin, and ACTH (Lanfranco et al., 2010). Somatostatin's GH inhibitory effect is mediated by the sst $_{2}$ (Briard et al., 1997), sst ${ }_{5}$ (Saveanu et al., 2001) and also sst 1 (Kreienkamp et al., 1999). The GH releasing effect of ghrelin is blunted by intravenous (iv) infusion of somatostatin in healthy volunteers (Di Vito et al., 2002) and was completely blocked in pig pituitary cells in vitro (Malagon et al., 2003). The GH releasing action of ghrelin is likely to not only result from inhibiting somatostatin release (Feng et al., 2011) but also from direct activation of GH release (Veldhuis et al., 2006). In addition, ghrelin and somatostatin antagonistically interact on hypothalamic arcuate cells to regulate the release of GHRH with an activation of these neurons following ghrelin and a reduction after application of somatostatin in vitro (Mori et al., 2010).

\section{ACTIVATION OF BRAIN sst2 2 SIGNALING INCREASES BASAL AND PREVENTS VISCERAL STRESS-INDUCED SUPPRESSION OF CIRCULATING GHRELIN}

Based on the established centrally sst ${ }_{2}$-mediated orexigenic action of somatostatin (Stengel et al., 2010a,d), we further investigated whether changes in circulating ghrelin may play a role. We found that the pan-somatostatin peptide, ODT8-SST (Table 1) injected icv increased basal plasma acyl ghrelin levels in ad libitum fed rats (Stengel et al., 2010a). However, the rise was observed at $3 \mathrm{~h}$ postinjection and therefore unlikely to underlie the initial increase in food intake response to central ODT8-SST which occurred within the first hour. However, it may contribute to the sustained significant increase in cumulative food intake still maintained at $4 \mathrm{~h}$ after icv injection of ODT8-SST (Stengel et al., 2010a). Other studies showed that activation of brain $s_{2} t_{2}$ receptor prevents the decline in circulating ghrelin induced by visceral stress. Abdominal surgery reproducibly decreased the fasting plasma levels of acyl and desacyl ghrelin with a rapid onset and long lasting effect in rats (Stengel et al., 2010b, 2011b,c). Such a response was completely prevented by the ic injection of ODT8-SST as monitored $50 \mathrm{~min}$ postsurgery at a time where the peptide induces a 31 and $46 \%$ rise in fasting circulating acyl and desacyl ghrelin, respectively in sham animals (Stengel et al., 2011b). In addition, the $s_{2} t_{2}$ selective peptide agonist injected ic also prevented the postoperative decline in plasma levels of acyl ghrelin, whereas $s t_{1}$ and $s_{4} t_{4}$ agonists (Table 1) did not when tested under the same conditions (Stengel et al., 2011b).

Of interest was the demonstration that ic ODT8-SST or sst $_{2}$ agonist in addition to preventing the decline in acyl ghrelin induced by abdominal surgery also blunted the postoperative suppression of food intake (Stengel et al., 2011b). However, the observed prevention of declining circulating ghrelin levels is not the main factor for the restoration of the orexigenic response postsurgically. The peripheral blockade of the GRLN-R using the GRLN-R antagonist ([D-Lys $\left.{ }^{3}\right]$-GHRP-6) injected intraperitoneally did not modify the food intake stimulating effect of ic ODT8-SST (Stengel et al., 2011b). ODT8-SST injected icv also restored gastric emptying inhibited by abdominal surgery to levels observed under basal conditions, an effect mimicked by the sst $_{5}$ but not the $\mathrm{sst}_{1}, \mathrm{sst}_{2}$, and $\mathrm{sst}_{4}$ agonists in rats (Stengel et al., 2011b). Similar to the effect on food intake, this action was not mediated by acyl ghrelin as the intraperitoneal injection of the GRLN-R antagonist did not influence the gastroprokinetic action of ODT8-SST postsurgery (Stengel et al., 2011b).

Taken together, these data indicate that the central activation of $\mathrm{sst}_{2}$ increases basal or prevents the surgical inhibition of circulating levels of ghrelin and food intake while activation of sst $_{5}$ restores postoperative gastric ileus in rats. It also points to a differential role of brain sst subtypes 2 and 5 in preventing the stress-related suppression of ghrelin release/food intake and gastric emptying, respectively. In addition, the restoration of suppressed circulating acyl ghrelin levels after surgery does not play a major role as underlying mechanisms through which ODT8-SST injected into the brain exerts its prokinetic and orexigenic effects. Other studies showed that activation of $s t_{2}$ and $s_{5} t_{5}$ receptors in the brain inhibits stimulated CRF release in the hypothalamus and acute stress-related CRF mediated ACTH release (Brown et al., 1984; Tizabi and Calogero, 1992; Saegusa et al., 2011; Tringali et al., 2012). Brain CRF acting on CRF receptors is involved in the stress-related decrease in feeding behavior, ghrelin secretion, and gastric emptying (Hotta et al., 1999; Sekino et al., 2004; Taché and Bonaz, 2007; Yakabi et al., 2011). Therefore, it may be speculated that central activation of $s t_{2}$ and/or sst $_{5}$ dampens hypothalamic CRF activated by abdominal surgery (Wang et al., 2011) which may have a bearing with preventing the reduction in feeding, gastric emptying, and circulating ghrelin induced by abdominal surgery (Stengel et al., 2011b).

\section{ACTIVATION OF PERIPHERAL sSt, ${ }_{2}$ SIGNALING INHIBITS CIRCULATING GHRELIN}

In contrast to the rise in circulating ghrelin induced by central administration of somatostatin agonists, convergent in vivo and in vitro rodent studies established that somatostatin or the stable agonists octreotide and SOM230 act peripherally through the sst $_{2}$ to reduce ghrelin release (Seoane et al., 2007; Iwakura et al., 2010; Lu et al., 2012) resulting in lower circulating levels (Shimada et al., 2003; Silva et al., 2005; de la Cour et al., 2007). Such a response is in line with the inhibitory effects of somatostatinsst $_{2}$ on the endocrine secretion of other intestinal hormones (Pederson et al., 1975; Marco et al., 1983; Rokaeus, 1984; Shiratori et al., 1991; Strowski etal., 2000). Likewise, in humans, peripherally injected somatostatin (Broglio et al., 2002; Norrelund etal., 2002) and somatostatin agonists such as octreotide (Barkan et al., 2003) reduce circulating ghrelin in healthy subjects. Of relevance, chronic subcutaneous infusion of the $s_{2} t_{2} /$ sst $_{3} / \mathrm{sst}_{5}$ agonist octreotide-induced suppression of ghrelin plasma levels is not subject to rapid desensitization in rats and is likely to be $s t_{2}$ mediated based on the prominent $s_{2} t_{2}$ mRNA expression in 
the rat stomach (Silva et al., 2005). Further support for a role of sst $_{2}$ came from immunofluorescent double labeling studies detecting the protein expression of sst $_{2}$ on ghrelin-producing X/A-like cells of the rat stomach (Stengel et al., 2011c) and similarly on human ghrelin-producing gastric mucosal $\mathrm{P} / \mathrm{D}_{1}$ cells (Fischer et al., 2008). Moreover, the selective peptide sst $_{2}$ agonist (Table 1) injected intravenously decreased circulating levels of acyl and desacyl ghrelin with a rapid onset $(0.5 \mathrm{~h})$ and a long duration of action (still visible at $2 \mathrm{~h}$; Stengel et al., 2011c). Lastly, the selective peptide $s_{2}{ }_{2}$ antagonist (Table 1) injected intravenously prevents the decline in circulating ghrelin induced by the stimulation of endogenous peripheral somatostatin in rats (Stengel et al., 2011c).

The physiological role of peripheral somatostatin-sst 2 signaling in the regulation of ghrelin was investigated under conditions of stimulation of endogenous gastric somatostatin. Urethane is well established to stimulate gastric somatostatin mRNA expression and peptide release in rats (Yang et al., 1990). Under these conditions, plasma ghrelin levels are decreased and the selective peptide $s_{2} t_{2}$ antagonist (Table 1) injected intravenously prevents the decline in circulating ghrelin induced by urethane (Stengel et al., 2011c). Convergent reports showed that abdominal surgery induces a rapid and sustained inhibition of circulating levels of ghrelin in rats (Stengel et al., 2010b, 2011b,c). Likewise, iv injection of the selective peptide $s t_{2}$ antagonist (Table 1) blocked the abdominal surgery-induced decrease of plasma ghrelin at $0.5 \mathrm{~h}$ postsurgery (Stengel et al., 2011c). The peptide is likely to act through paracrine transmission since somatostatin positive $\mathrm{D}$ cells directly contact ghrelin immunoreactive X/A-like cells in the rat stomach (Shimada et al., 2003). Interestingly, following abdominal surgery, acyl ghrelin was reduced more rapidly compared to desacyl ghrelin which was associated with a reduction of gastric as well as plasma concentrations of GOAT (Stengel et al., 2011c). Since blockade of peripheral $\mathrm{sst}_{2}$ signaling restores circulating levels of ghrelin (Stengel et al., 2011c), these data collectively suggest that peripheral somatostatin may blunt gastric GOAT mRNA expression and thereby negatively affect the acylation of ghrelin. In primary pituitary cell cultures somatostatin was reported to reduce GOAT mRNA expression and somatostatin knockout mice showed higher GOAT mRNA expression in the pituitary gland than the wild type (Gahete et al., 2010b). Based on these findings, somatostatin may influence ghrelin signaling not only via a direct inhibition of secretion but also by modulating the ghrelin activating enzyme GOAT. Further support for a physiological inhibitory action of peripheral somatostatin on ghrelin signaling came from somatostatin knockout mice that displayed an increased gastric ghrelin expression and higher circulating ghrelin levels compared to their wild type littermates (Luque et al., 2006a). These data indicate that endogenous somatostatin exerts a physiological inhibitory tone on gastric ghrelin synthesis and release.

During the past years, several clinical studies described ghrelinproducing NETs (Papotti et al., 2001; Volante et al., 2002; Taal and Visser, 2004) including six insulinomas, gastrinomas, vasoactive intestinal polypeptide (VIP)omas, non-functioning tumors (Volante et al., 2002) and as part of the multiple endocrine neoplasia type 1 (MEN-1; Iwakura et al., 2002; Raffel et al., 2005;
Ekeblad et al., 2007). Moreover, ghrelinomas have been identified to originate from the stomach or pancreas and were associated with very high ghrelin levels (Corbetta et al., 2003; Tsolakis et al., 2004). Growing evidence from clinical reports indicates that in addition to the surgical, chemotherapeutic, alpha-interferon, and local radiation treatments, the use of somatostatin or somatostatin analog is an established treatment option for gastroenteropancreatic NETs (Pavel and Wiedenmann, 2011). Based on the evidence described above, the determination of the sst subtype expressed on those ghrelinoma tumor cells followed by the use of peripherally acting selective sst compounds may result in an even more targeted approach.

\section{INTERACTION OF CORTISTATIN WITH GHRELIN SIGNALING}

In 1996, the discovery of a new peptide sharing 11 of its 14 amino acids with somatostatin-14 was named cortistatin based on its predominant cortical expression and ability to depress cortical activity (de Lecea et al., 1996). Despite the chemical structure homology with somatostatin, both peptides are derived from distinct genes (de Lecea et al., 1997b). Similar to pro-somatostatin, processing of cortistatin precursor generated two mature products, cortistatin-14 and -29 in rodents and cortistatin-17 and -29 in humans (Fukusumi et al., 1997; Spier and de Lecea, 2000). Cortistatin is widely expressed in the brain, namely in the cortex and hippocampus, and although regional overlap exists, the distribution pattern differs from that of somatostatin (de Lecea et al., 1997a). Likewise, the peripheral expression pattern of cortistatin (e.g., in adrenal, thyroid, and parathyroid gland, testis, pancreas, kidney, lung, liver, stomach, ileum, jejunum, colon, endothelial, and immune cells) does not fully match that of somatostatin (Papotti et al., 2003; Dalm et al., 2004; Xidakis et al., 2007). Consistent with being a close somatostatin endogenous analog, cortistatin contains the FWKT tetramer crucial for sst binding, and therefore displays high-affinity (1-2 nM) to all five sst subtypes where the peptide acts as an agonist (Fukusumi et al., 1997; Siehler et al., 2008). However, emerging evidence indicates that cortistatin induces distinct central and peripheral effects that differ from those exerted by the somatostatin-sst interaction such as central acetylcholine release, reduction of locomotor activity, depression of cortical activity, induction of slow wave sleep, anti-inflammatory and immunomodulatory effects, and reduction of vascular calcium deposition (for review, see Spier and de Lecea, 2000; Broglio et al., 2007; Gonzalez-Rey and Delgado, 2008).

The existence of a specific cortistatin receptor has not been identified yet but differential actions between somatostatin and cortistatin may possibly reside in the ability of cortistatin to bind and to activate the GRLN-R, whereas somatostatin does not (Deghenghi et al., 2001b; Muccioli et al., 2001). Divergent from native somatostatin, however, synthetic somatostatin agonists, lanreotide, octreotide, and vapreotide bind to the GRLN-R in human pituitary tissue (Deghenghi et al., 2001c) in addition to their selective affinity for $\mathrm{sst}_{2}>\mathrm{sst}_{5}>\mathrm{sst}_{3}$ (Bauer et al., 1982; Reichlin, 1983; Redding and Schally, 1984). In addition to binding studies, few functional findings also support the possibility that cortistatin may be another endogenous high-affinity ligand of the 
GRLN-R. Cortistatin has been reported to inhibit vascular calcification induced experimentally in rats through activation of the GRLN-R receptor rather than sst or Mrg X2 (Liu et al., 2010). Of interest was the demonstration that cortistatin selectively upregulates the GRLN-R mRNA expression in cultured rat vascular smooth muscle cells, further indicative of an interaction between cortistatin and ghrelin signaling (Liu et al., 2010). Other studies in primates and mice demonstrated that endogenous cortistatin, unlike somatostatin, is involved in the stimulation of pituitary prolactin release, an effect that is blocked in vitro by the GRLN-R antagonist (Cordoba-Chacon et al., 2011). However, most of the endocrine studies performed in vivo or in vitro showed parallel inhibitory responses between cortistatin and somatostatin consistent with the activation of classical sst subtypes (Broglio et al., 2008) with some exceptions (Prodam et al., 2008). This is further corroborated by the finding that cortistatin knockout mice display elevated circulating acyl ghrelin levels associated with an upregulated gastric ghrelin and GOAT expression (Cordoba-Chacon et al., 2011) indicating an inhibitory tone of endogenous cortistatin on ghrelin signaling.

To further delineate the actions of cortistatin mediated via the GRLN-R another peptide, cortistatin-8, has been shown to bind to the GRLN-R while being devoid of affinity to the sst subtypes (Luque et al., 2006b). However, in one clinical study cortistatin-8 did not influence spontaneous pituitary hormone secretion $(\mathrm{GH}$, prolactin, and $\mathrm{ACTH})$ and did not interfere with ghrelin's endocrine responses when given in equimolar dose ratios in healthy human subjects (Prodam et al., 2008). Therefore,

\section{REFERENCES}

Ariyasu, H., Takaya, K., Tagami, T., Ogawa, Y., Hosoda, K., Akamizu, T., etal. (2001). Stomach is a major source of circulating ghrelin, and feeding state determines plasma ghrelin-like immunoreactivity levels in humans. J. Clin. Endocrinol. Metab. 86, 4753-4758.

Banks, W. A., Tschöp, M., Robinson, S. M., and Heiman, M. L. (2002). Extent and direction of ghrelin transport across the blood-brain barrier is determined by its unique primary structure. J. Pharmacol. Exp. Ther. 302, 822-827.

Baragli, A., Alturaihi, H., Watt, H. L., Abdallah, A., and Kumar, U. (2007). Heterooligomerization of human dopamine receptor 2 and somatostatin receptor 2 co-immunoprecipitation and fluorescence resonance energy transfer analysis. Cell. Signal. 19, 2304-2316.

Barkan, A. L., Dimaraki, E. V., Jessup, S. K., Symons, K. V., Ermolenko, M., and Jaffe, C. A. (2003). Ghrelin secretion in humans is sexually dimorphic, suppressed by somatostatin, and not affected by the ambient growth hormone levels. J. Clin. Endocrinol. Metab. 88, 21802184.
Bauer, W., Briner, U., Doepfner, W. Haller, R., Huguenin, R., Marbach, P., et al. (1982). SMS 201-995: a very potent and selective octapeptide analogue of somatostatin with prolonged action. Life Sci. 31, 11331140.

Bertherat, J., Bluet-Pajot, M. T. and Epelbaum, J. (1995). Neuroendocrine regulation of growth hormone. Eur. J. Endocrinol. 132, 12-24.

Bradette, M., Delvaux, M., Staumont, G., Fioramonti, J., Bueno, L. and Frexinos, J. (1994). Octreotide increases thresholds of colonic visceral perception in IBS patients without modifying muscle tone. Dig. Dis. Sci. 39, 1171-1178

Brazeau, P., Vale, W., Burgus, R., Ling, N., Butcher, M., Rivier, J., et al. (1973). Hypothalamic polypeptide that inhibits the secretion of immunoreactive pituitary growth hormone. Science 179, 77-79.

Briard, N., Dutour, A., Epelbaum, J., Sauze, N., Slama, A., and Oliver, C. (1997). Species differences between male rat and ram pituitary somatostatin receptors involved in the inhibition of growth hormone secretion. Eur. J. Endocrinol. 137, 545-555.

Broglio, F., Grottoli, S., Arvat, E., and Ghigo, E. (2008). Endocrine actions

additional specific tools may be needed to characterize a possible direct link between the ghrelin and somatostatin signaling system via interaction on the GRLN-R.

\section{SUMMARY}

In summary, somatostatin robustly affects circulating levels of ghrelin through interaction with the $\mathrm{sst}_{2}$. However, alterations vary with the site of action. Central somatostatin elevates plasma levels of acyl and desacyl ghrelin via interaction with brain sst $_{2}$ and counteracts the visceral stress-related decrease in circulating ghrelin through pathways still to be elucidated in rodents. By contrast, the activation of peripheral somatostatin-sst ${ }_{2}$ inhibits circulating ghrelin levels in experimental and clinical studies and mediates the decline in circulating ghrelin induced by abdominal surgery in rodents likely via a paracrine action of somatostatin on sst $_{2}$ bearing ghrelin cells in the stomach. Of interest, cortistatin, the other member of the somatostatin family, in addition to binding to sst $_{1-5}$, also binds to and activates the GRLN-R. There is evidence that the peptide can exert a dual influence on ghrelin, by inhibiting its release through interaction with sst 2 located on gastric ghrelin cells while activating GRLN-R at ghrelin's tissue targets.

\section{ACKNOWLEDGMENTS}

This work was supported by NIH R01 DK-33061, NIH Center Grant DK-41301 (Animal Core), VA Research Career Scientist and VA Merit grant (to Yvette Taché), German Research Foundation STE 1765/3-1 (to Andreas Stengel), and Charité University Funding UFF 89-441-176 (to Andreas Stengel).

of cortistatin: in vivo studies. $\mathrm{Mol}$ Cell. Endocrinol. 286, 123-127.

Broglio, F., Papotti, M., Muccioli, G. and Ghigo, E. (2007). Brain-gut communication: cortistatin, somatostatin and ghrelin. Trends Endocrinol. Metab. 18, 246-251.

Broglio, F., Van Koetsveld, P., Benso, A., Gottero, C., Prodam, F., Papotti, M., etal. (2002). Ghrelin secretion is inhibited by either somatostatin or cortistatin in humans. J. Clin. Endocrinol. Metab. 87, 48294832.

Brown, M. R., Rivier, C., and Vale, W. (1984). Central nervous system regulation of adrenocorticotropin secretion: role of somatostatins. Endocrinology 114, 1546-1549.

Cescato, R., Erchegyi, J., Waser, B., Piccand, V., Maecke, H. R., Rivier, J. E., et al. (2008). Design and in vitro characterization of highly sst2-selective somatostatin antagonists suitable for radiotargeting. J. Med. Chem. 51, 4030-4037.

Corbetta, S., Peracchi, M., Cappiello, V., Lania, A., Lauri, E. Vago, L., etal. (2003). Circulating ghrelin levels in patients with pancreatic and gastrointestinal neuroendocrine tumors: identification of one pancreatic ghrelinoma. J. Clin. Endocrinol. Metab. 88, 31173120.

Cordoba-Chacon, J., Gahete, M. D., Culler, M. D., Castano, J. P., Kineman, R. D., and Luque, R. M. (2012). Somatostatin dramatically stimulates growth hormone release from primate somatotrophs acting at low doses via somatostatin receptor 5 and cyclic AMP. J. Neuroendocrinol. 24, 453-463.

Cordoba-Chacon, J., Gahete, M. D., Pozo-Salas, A. I., Martinez-Fuentes, A. J., de Lecea, L., Gracia-Navarro, F., et al. (2011). Cortistatin is not a somatostatin analogue but stimulates prolactin release, and inhibits $\mathrm{GH}$ and $\mathrm{ACTH}$ in a gender-dependent fashion: potential role of ghrelin. Endocrinology 152, 4800-4812.

Corleto, V. D., Severi, C., Romano, G., Tattoli, I., Weber, H. C., Stridsberg, M., et al. (2006). Somatostatin receptor subtypes mediate contractility on human colonic smooth muscle cells. Neurogastroenterol. Motil. 18, 217-225.

Costa, M., Patel, Y., Furness, J. B., and Arimura, A. (1977). Evidence that some intrinsic neurons of the intestine contain somatostatin. Neurosci. Lett. 6, 215-222. 
Culler, M. D., Oberg, K., Arnold, R., Krenning, E. P., Sevilla, I., and Diaz, J. A. (2011). Somatostatin analogs for the treatment of neuroendocrine tumors. Cancer Metastasis Rev. 30(Suppl. 1), 9-17.

Cummings, D. E., Purnell, J. Q., Frayo, R. S., Schmidova, K., Wisse, B. E., and Weigle, D. S. (2001). A preprandial rise in plasma ghrelin levels suggests a role in meal initiation in humans. Diabetes. 50, 1714 1719.

Cummings, D. E., Weigle, D. S., Frayo, R. S., Breen, P. A., Ma, M. K., Dellinger, E. P., et al. (2002). Plasma ghrelin levels after diet-induced weight loss or gastric bypass surgery. N. Engl. J. Med. 346, 1623-1630.

Dalm, V. A., Van Hagen, P. M., de Krijger, R. R., Kros, J. M., Van Koetsveld, P. M., Van Der Lely, A. J., et al. (2004). Distribution pattern of somatostatin and cortistatin mRNA in human central and peripheral tissues. Clin. Endocrinol. (Oxf.) 60, 625-629.

Damian, M., Marie, J., Leyris, J. P., Fehrentz, J. A., Verdie, P., Martinez, J., et al. (2012). High constitutive activity is an intrinsic feature of ghrelin receptor protein: a study with a functional monomeric GHS-R1a receptor reconstituted in lipid discs. J. Biol. Chem. 287, 3630-3641.

Date, Y., Murakami, N., Toshinai, K., Matsukura, S., Niijima, A., Matsuo, H., et al. (2002). The role of the gastric afferent vagal nerve in ghrelin-induced feeding and growth hormone secretion in rats. Gastroenterology 123, 1120-1128.

Davenport, A. P., Bonner, T. I., Foord, S. M., Harmar, A. J., Neubig, R. R., Pin, J. P., et al. (2005). International Union of Pharmacology. LVI. Ghrelin receptor nomenclature, distribution, and function. Pharmacol. Rev. 57, 541-546.

Davies, J. S., Kotokorpi, P., Eccles, S. R., Barnes, S. K., Tokarczuk, P. F., Allen, S. K., et al. (2009). Ghrelin induces abdominal obesity via GHSR-dependent lipid retention. Mol. Endocrinol. 23, 914-924.

Deghenghi, R., Avallone, R., Torsello, A. Muccioli, G., Ghigo, E., and Locatelli, V. (2001a). Growth hormoneinhibiting activity of cortistatin in the rat. J. Endocrinol. Invest. 24, RC31-RC33.

Deghenghi, R., Papotti, M., Ghigo, E., and Muccioli, G. (2001b). Cortistatin, but not somatostatin, binds to growth hormone secretagogue (GHS) receptors of human pituitary gland. J. Endocrinol. Invest. 24, RC1RC33.
Deghenghi, R., Papotti, M., Ghigo, E., Muccioli, G., and Locatelli, V. (2001c). Somatostatin octapeptides (lanreotide, octreotide, vapreotide, and their analogs) share the growth hormone-releasing peptide receptor in the human pituitary gland. Endocrine 14, 29-33.

de Heer, J., Rasmussen, C., Coy, D. H., and Holst, J. J. (2008) Glucagon-like peptide-1, but not glucose-dependent insulinotropic peptide, inhibits glucagon secretion via somatostatin (receptor subtype 2 ) in the perfused rat pancreas. Diabetologia 51, 2263-2270.

de la Cour, C. D., Norlen, P., and Hakanson, R. (2007). Secretion of ghrelin from rat stomach ghrelin cells in response to local microinfusion of candidate messenger compounds: a microdialysis study. Regul. Pept. 143, 118-126.

de Lecea, L., Criado, J. R., ProsperoGarcia, O., Gautvik, K. M., Schweitzer, P., Danielson, P. E., et al. (1996). A cortical neuropeptide with neuronal depressant and sleepmodulating properties. Nature 381, 242-245.

de Lecea, L., del Rio, J. A., Criado, J. R. Alcantara, S., Morales, M., Danielson, P. E., et al. (1997a). Cortistatin is expressed in a distinct subset of cortical interneurons. J Neurosci. 17 5868-5880.

de Lecea, L., Ruiz-Lozano, P., Danielson, P. E., Peelle-Kirley, J., Foye, P. E., Frankel, W. N., etal. (1997b). Cloning, mRNA expression, and chromosomal mapping of mouse and human preprocortistatin. Genomics 42, 499-506.

Di Vito, L., Broglio, F., Benso, A., Gottero, C., Prodam, F., Papotti, M., et al. (2002). The GH-releasing effect of ghrelin, a natural GH secretagogue, is only blunted by the infusion of exogenous somatostatin in humans. Clin. Endocrinol. (Oxf.) 56, 643-648.

Druce, M. R., Wren, A. M., Park, A. J., Milton, J. E., Patterson, M., Frost, G., et al. (2005). Ghrelin increases food intake in obese as well as lean subjects. Int. J. Obes. (Lond.) 29, 1130 1136.

Ekeblad, S., Lejonklou, M. H., Grimfjard, P., Johansson, T., Eriksson, B., Grimelius, L., et al. (2007). Coexpression of ghrelin and its receptor in pancreatic endocrine tumours. Clin. Endocrinol. (Oxf.) 66, 115-122.

Erchegyi, J., Cescato, R., Grace, C. R., Waser, B., Piccand, V., Hoyer, D., et al. (2009). Novel, potent, and radioiodinatable somatostatin receptor 1 $\left(\mathrm{sst}_{1}\right)$ selective analogues. J. Med. Chem. 52, 2733-2746.
Erchegyi, J., Grace, C. R., Samant, M., Cescato, R., Piccand, V., Riek, R., et al. (2008). Ring size of somatostatin analogues (ODT-8) modulates receptor selectivity and binding affinity. $J$. Med. Chem. 51, 2668-2675.

Fehlmann, D., Langenegger, D., Schuepbach, E., Siehler, S., Feuerbach, D. and Hoyer, D. (2000). Distribution and characterisation of somatostatin receptor mRNA and binding sites in the brain and periphery. J. Physiol. Paris 94, 265-281.

Feifel, D., and Vaccarino, F. J. (1990). Central somatostatin: a reexamination of its effects on feeding. Brain Res. 535, 189-194.

Feng, D. D., Yang, S. K., Loudes, C., Simon, A., Al-Sarraf, T., Culler, M. et al. (2011). Ghrelin and obestatin modulate growth hormone-releasing hormone release and synaptic inputs onto growth hormone-releasing hormone neurons. Eur. J. Neurosci. 34 732-744.

Finley, J. C., Maderdrut, J. L., Roger, L. J., and Petrusz, P. (1981). The immunocytochemical localization of somatostatin-containing neurons in the rat central nervous system. $\mathrm{Neu}$ roscience 6, 2173-2192.

Fischer, T., Doll, C., Jacobs, S., Kolodziej, A., Stumm, R., and Schulz, S. (2008). Reassessment of sst2 somatostatin receptor expression in human normal and neoplastic tissues using the novel rabbit monoclonal antibody UMB-1. J. Clin. Endocrinol. Metab. 93, 45194524.

Fukusumi, S., Kitada, C., Takekawa, S., Kizawa, H., Sakamoto, J., Miyamoto, M., et al. (1997). Identification and characterization of a novel human cortistatin-like peptide. Biochem. Biophys. Res. Commun. 232, 157-163.

Gahete, M. D., Cordoba-Chacon, J., Duran-Prado, M., Malagon, M. M., Martinez-Fuentes, A. J., GraciaNavarro, F., et al. (2010a). Somatostatin and its receptors from fish to mammals. Ann. N. Y. Acad. Sci. 1200 , 43-52.

Gahete, M. D., Cordoba-Chacon, J., Salvatori, R., Castano, J. P., Kineman, R. D., and Luque, R. M. (2010b). Metabolic regulation of ghrelin $\mathrm{O}$-acyl transferase (GOAT) expression in the mouse hypothalamus, pituitary, and stomach. Mol. Cell. Endocrinol. 317, 154-160.

Gardi, J., Obal, F. Jr., Fang, J., Zhang, J., and Krueger, J. M. (1999). Diurnal variations and sleep deprivationinduced changes in rat hypothalamic GHRH and somatostatin contents. Am. J. Physiol. 277, R1339-R1344.
Giovacchini, G., Nicolas, G., and Forrer, F. (2012). Peptide receptor radionuclide therapy with somatostatin analogues in neuroendocrine tumors. Anticancer Agents Med. Chem. 12, 526-542.

Gonzalez, C. R., Vazquez, M. J., Lopez, M., and Dieguez, C. (2008). Influence of chronic undernutrition and leptin on GOAT mRNA levels in rat stomach mucosa. J. Mol. Endocrinol. 41, 415-421.

Gonzalez-Rey, E., and Delgado, M. (2008). Emergence of cortistatin as a new immunomodulatory factor with therapeutic potential in immune disorders. Mol. Cell. Endocrinol. 286, 135-140.

Grace, C. R., Erchegyi, J., Koerber, S. C., Reubi, J. C., Rivier, J., and Riek, R. (2006). Novel sst2-selective somatostatin agonists. Three-dimensional consensus structure by NMR. J. Med. Chem. 49, 4487-4496.

Grace, C. R., Erchegyi, J., Samant, M., Cescato, R., Piccand, V., Riek, R., et al. (2008). Ring size in octreotide amide modulates differently agonist versus antagonist binding affinity and selectivity. J. Med. Chem. 51, 26762681.

Gregersen, T., Gronbaek, H., Worsoe, J., Schlageter, V., Laurberg, S., and Krogh, K. (2011). Effects of Sandostatin LAR on gastrointestinal motility in patients with neuroendocrine tumors. Scand. J. Gastroenterol. 46, 895-902.

Guillemin, R. (2011). Neuroendocrinology: a short historical review. Ann. N. Y. Acad. Sci. 1220, $1-5$.

Gutierrez, J. A., Solenberg, P. J., Perkins, D. R., Willency, J. A., Knierman, M. D., Jin, Z., et al. (2008). Ghrelin octanoylation mediated by an orphan lipid transferase. Proc. Natl. Acad. Sci. U.S.A. 105, 6320-6325.

Hotta, M., Shibasaki, T., Arai, K., and Demura, H. (1999). Corticotropinreleasing factor receptor type 1 mediates emotional stress-induced inhibition of food intake and behavioral changes in rats. Brain Res. 823, 221-225.

Ishikawa, M., Mizobuchi, M., Takahashi, H., Bando, H., and Saito, S. (1997). Somatostatin release as measured by in vivo microdialysis: circadian variation and effect of prolonged food deprivation. Brain Res. 749, 226-231.

Iwakura, H., Hosoda, K., Doi, R., Komoto, I., Nishimura, H., Son, C., et al. (2002). Ghrelin expression in islet cell tumors: augmented expression of ghrelin in a case of glucagonoma with multiple 
endocrine neoplasm type I. J. Clin. Endocrinol. Metab. 87, 4885-4888.

Iwakura, H., Li, Y., Ariyasu, H., Hosoda, H., Kanamoto, N., Bando, M., et al. (2010). Establishment of a novel ghrelin-producing cell line. Endocrinology 151, 2940-2945.

Jawiarczyk, A., Bolanowski, M., Syrycka, J., Bednarek-Tupikowska, G., Kaluzny, M., Kolodziejczyk, A., etal. (2012). Effective therapy of insulinoma by using long-acting somatostatin analogue. A case report and literature review. Exp. Clin. Endocrinol. Diabetes 120, 68-72.

Johansson, O., Hokfelt, T., and Elde, R. P. (1984). Immunohistochemical distribution of somatostatin-like immunoreactivity in the central nervous system of the adult rat. Neuroscience 13, 265-339.

Kang, K., Schmahl, J., Lee, J. M., Garcia, K., Patil, K, Chen, A. etal. (2012). Mouse ghrelin-Oacyltransferase (GOAT) plays a critical role in bile acid reabsorption. FASEB J. 26, 259-271.

Kim, M. S., Yoon, C. Y., Park, K. H., Shin, C. S., Park, K. S., Kim, S. Y., et al. (2003). Changes in ghrelin and ghrelin receptor expression according to feeding status. Neuroreport 14 , 1317-1320.

Kineman, R. D., and Luque, R. M. (2007). Evidence that ghrelin is as potent as growth hormone $(\mathrm{GH})$-releasing hormone (GHRH) in releasing $\mathrm{GH}$ from primary pituitary cell cultures of a nonhuman primate (Papio anubis), acting through intracellular signaling pathways distinct from GHRH. Endocrinology 148, 4440-4449.

Kojima, M., Hosoda, H., Date, Y., Nakazato, M., Matsuo, H., and Kangawa, K. (1999). Ghrelin is a growthhormone-releasing acylated peptide from stomach. Nature 402, 656-660.

Kojima, M., Hosoda, H., Matsuo, H., and Kangawa, K. (2001). Ghrelin: discovery of the natural endogenous ligand for the growth hormone secretagogue receptor. Trends Endocrinol. Metab. 12, 118-122.

Kojima, M., and Kangawa, K. (2005). Ghrelin: structure and function. Physiol Rev. 85, 495-522.

Kojima, M., and Kangawa, K. (2011). The discovery of ghrelin: with a little luck and great passion. Peptides 32, 2153-2154.

Kreienkamp, H. J., Akgun, E., Baumeister, H., Meyerhof, W., and Richter, D. (1999). Somatostatin receptor subtype 1 modulates basal inhibition of growth hormone release in somatotrophs. FEBS Lett. 462, 464-466.
Lanfranco, F., Motta, G., Baldi, M., Gasco, V., Grottoli, S., Benso, A., et al. (2010). Ghrelin and anterior pituitary function. Front. Horm. Res. 38, 206-211.

Lim, C. T., Kola, B., Grossman, A., and Korbonits, M. (2011). The expression of ghrelin $\mathrm{O}$-acyltransferase (GOAT) in human tissues. Endocr. J. 8, 707-710.

Liu, Y., Zhou, Y. B., Zhang, G. G., Cai, Y., Duan, X. H., Teng, X., et al. (2010). Cortistatin attenuates vascular calcification in rats. Regul. Pept. 159, 35-43.

Lloyd, K. C., Amirmoazzami, S., Friedik, F., Chew, P., and Walsh, J. H. (1997). Somatostatin inhibits gastrin release and acid secretion by activating sst 2 in dogs. Am. J. Physiol. 272, G1481G1488.

Lu, X., Zhao, X., Feng, J., Liou, A. P., Anthony, S., Pechhold, S. et al. (2012). Postprandial inhibition of gastric ghrelin secretion by longchain fatty acid (LCFA) through GPR 120 in isolated gastric ghrelin cells and mice. Am. J. Physiol. Gastrointest. Liver Physiol. 303, G367-G376.

Ludvigsen, E., Olsson, R., Stridsberg, M., Janson, E. T., and Sandler, S. (2004). Expression and distribution of somatostatin receptor subtypes in the pancreatic islets of mice and rats. J. Histochem. Cytochem. 52, 391-400. Luque, R. M., Gahete, M. D. Hochgeschwender, U., and Kineman, R. D. (2006a). Evidence that endogenous SST inhibits ACTH and ghrelin expression by independent pathways. Am. J. Physiol. Endocrinol. Metab. 291, E395-E403.

Luque, R. M., Peinado, J. R., GraciaNavarro, F., Broglio, F., Ghigo, E., Kineman, R. D., et al. (2006b). Cortistatin mimics somatostatin by inducing a dual, dose-dependent stimulatory and inhibitory effect on growth hormone secretion in somatotropes. J. Mol. Endocrinol. 36 547-556.

Malagon, M. M., Luque, R. M., RuizGuerrero, E., Rodriguez-Pacheco, F., Garcia-Navarro, S., Casanueva, F. F., et al. (2003). Intracellular signaling mechanisms mediating ghrelinstimulated growth hormone release in somatotropes. Endocrinology 144 5372-5380.

Marco, J., Correas, I., Zulueta, M. A., Vincent, E., Coy, D. H., Comaru-Schally, A. M., et al. (1983). Inhibitory effect of somatostatin-28 on pancreatic polypeptide, glucagon and insulin secretion in normal man. Horm. Metab. Res. 15, 363-366.

Martinez, V., Rivier, J., Coy, D. and Taché, Y. (2000). Intracisternal injection of somatostatin receptor 5 preferring agonists induces a vagal cholinergic stimulation of gastric emptying in rats. J. Pharmacol. Exp. Ther. 293, 1099-1105.

Moga, M. M., and Gray, T. S. (1985). Evidence for corticotropin-releasing factor, neurotensin, and somatostatin in the neural pathway from the central nucleus of the amygdala to the parabrachial nucleus. J. Comp. Neurol. 241, 275-284.

Mönnikes, H., Raybould, H. E. Schmidt, B., and Taché, Y. (1993) CRF in the paraventricular nucleus of the hypothalamus stimulates colonic motor activity in fasted rats. Peptides 14, 743-747.

Mönnikes, H., Schmidt, B. G., Tebbe, J., Bauer, C., and Taché, Y. (1994). Microinfusion of corticotropin releasing factor into the locus coeruleus/subcoeruleus nucle stimulates colonic motor function in rats. Brain Res. 644, 101-108.

Mori, K., Kim, J., and Sasaki, K. (2010). Electrophysiological effect of ghrelin and somatostatin on rat hypothalamic arcuate neurons in vitro. Peptides 31, 1139-1145.

Muccioli, G., Papotti, M., Locatelli, V., Ghigo, E., and Deghenghi, R. (2001). Binding of ${ }^{125}$ I-labeled ghrelin to membranes from human hypothalamus and pituitary gland. J. Endocrinol. Invest. 24, RC7-RC9.

Nishi, Y., Hiejima, H., Hosoda, H., Kaiya, H., Mori, K., Fukue, Y., et al. (2005). Ingested medium-chain fatty acids are directly utilized for the acyl modification of ghrelin. Endocrinology 146, 2255-2264.

Norrelund, H., Hansen, T. K., Orskov, H., Hosoda, H., Kojima, M., Kangawa, K., et al. (2002). Ghrelin immunoreactivity in human plasma is suppressed by somatostatin. Clin. Endocrinol. (Oxf) 57, 539-546.

Pan, W., Tu, H., and Kastin, A. J. (2006). Differential BBB interactions of three ingestive peptides: obestatin, ghrelin, and adiponectin. Peptides 27, 911-916.

Papotti, M., Cassoni, P., Volante, M., Deghenghi, R., Muccioli, G., and Ghigo, E. (2001). Ghrelin-producing endocrine tumors of the stomach, and intestine. J. Clin. Endocrinol. Metab. 86, 5052-5059.

Papotti, M., Tarabra, E., Allia, E., Bozzalla-Cassione, F., Broglio, F., Deghenghi, R., et al. (2003). Presence of cortistatin in the human pancreas. J. Endocrinol. Invest. 26, RC15-RC18.

Pavel, M. E., and Wiedenmann, B. (2011). Novel therapeutic agents for the treatment of gastroenteropancreatic neuroendocrine tumors. Horm. Metab. Res. 43, 844-853.

Pederson, R. A., Dryburgh, J. R., and Brown, J. C. (1975). The effect of somatostatin on release and insulinotropic action of gastric inhibitory polypeptide. Can. J. Physiol. Pharmacol. 53, 1200-1205.

Pfluger, P. T., Kirchner, H., Gunnel, S., Schrott, B., Perez-Tilve, D., Fu, S., et al. (2008). Simultaneous deletion of ghrelin and its receptor increases motor activity and energy expenditure. Am. J. Physiol. Gastrointest. Liver Physiol. 294, G610-G618.

Piqueras, L., Taché, Y., and Martinez, V. (2003). Somatostatin receptor type 2 mediates bombesin-induced inhibition of gastric acid secretion in mice. J. Physiol. 549, 889-901.

Pradayrol, L., Jornvall, H., Mutt, V., and Ribet, A. (1980). N-terminally extended somatostatin: the primary structure of somatostatin-28. FEBS Lett. 109, 55-58.

Prodam, F., Benso, A., Gramaglia, E., Lucatello, B., Riganti, F., van der Lely, A. J., et al. (2008). Cortistatin-8, a synthetic cortistatin-derived ghrelin receptor ligand, does not modify the endocrine responses to acylated ghrelin or hexarelin in humans. Neuropeptides 42, 89-93.

Raffel, A., Krausch, M., Cupisti, K., Gerharz, C. D., Eisenberger, C. F., and Knoefel, W. T. (2005). Ghrelin expression in neuroendocrine tumours of the gastrointestinal tract with multiple endocrine neoplasia type 1. Horm. Metab. Res. 37, 653-655.

Redding, T. W., and Schally, A. V. (1984). Inhibition of growth of pancreatic carcinomas in animal models by analogs of hypothalamic hormones. Proc. Natl. Acad. Sci. U.S.A. 81, 248-252.

Reichlin, S. (1983). Somatostatin. N. Engl. J. Med. 309, 1495-1501.

Rocheville, M., Lange, D. C., Kumar, U., Sasi, R., Patel, R. C., and Patel, Y. C. (2000). Subtypes of the somatostatin receptor assemble as functional homo- and heterodimers. J. Biol. Chem. 275, 7862-7869.

Rodriguez, A., Gomez-Ambrosi, J., Catalan, V., Rotellar, F., Valenti, V., Silva, C., etal. (2012). The ghrelin $\mathrm{O}$-acyltransferase-ghrelin system reduces TNF-alpha-induced apoptosis and autophagy in human visceral adipocytes. Diabetologia 55, 30383050.

Rokaeus, A. (1984). Increase in neurotensin-like immunoreactivity in rat plasma after administration of calcium, bombesin and fat and 
its inhibition by somatostatin. Acta Physiol. Scand. 122, 261-267.

Rong, W., Winchester, W. J., and Grundy, D. (2007). Spontaneous hypersensitivity in mesenteric afferent nerves of mice deficient in the sst 2 subtype of somatostatin receptor. $J$. Physiol. 581, 779-786.

Saegusa, Y., Takeda, H., Muto, S., Nakagawa, K., Ohnishi, S., Sadakane, C., et al. (2011). Decreased plasma ghrelin contributes to anorexia following novelty stress. Am. J. Physiol. Endocrinol. Metab. 301, E685-E696.

Sakata, I., Yamazaki, M., Inoue, K., Hayashi, Y., Kangawa, K., and Sakai, T. (2003). Growth hormone secretagogue receptor expression in the cells of the stomach-projected afferent nerve in the rat nodose ganglion. Neurosci. Lett. 342, 183-186.

Sakata, I., Yang, J., Lee, C. E., OsborneLawrence, S., Rovinsky, S. A., Elmquist, J. K., et al. (2009). Colocalization of ghrelin $\mathrm{O}$-acyltransferase and ghrelin in gastric mucosal cells. Am. J. Physiol. Endocrinol. Metab. 297, E134-E141.

Salome, N., Haage, D., Perrissoud, D., Moulin, A., Demange, L., Egecioglu, E., et al. (2009). Anorexigenic and electrophysiological actions of novel ghrelin receptor (GHS-R1A) antagonists in rats. Eur. J. Pharmacol. 612, 167-173.

Saveanu, A., Gunz, G., Dufour, H., Caron, P., Fina, F., Ouafik, L., et al. (2001). Bim-23244, a somatostatin receptor subtype 2 - and 5-selective analog with enhanced efficacy in suppressing growth hormone (GH) from octreotide-resistant human GH-secreting adenomas. J. Clin. Endocrinol. Metab. 86, 140-145.

Schafer, J., and Meyerhof, W. (1999). sstl mRNA is the prominent somatostatin receptor mRNA in the rat gastrointestinal tract: reverse transcription polymerase chain reaction and in situ-hybridization study. $\mathrm{Neu}$ ropeptides 33, 457-463.

Schulz, S., Handel, M., Schreff, M., Schmidt, H., and Hollt, V. (2000). Localization of five somatostatin receptors in the rat central nervous system using subtype-specific antibodies. J. Physiol. Paris 94, 259-264.

Schwetz, I., Naliboff, B., Munakata, J., Lembo, T., Chang, L., Matin, K., etal. (2004). Anti-hyperalgesic effect of octreotide in patients with irritable bowel syndrome. Aliment. Pharmacol. Ther. 19, 123-131.

Sekino, A., Ohata, H., Mano-Otagiri, A., Arai, K., and Shibasaki, T.
(2004). Both corticotropin-releasing factor receptor type 1 and type 2 are involved in stress-induced inhibition of food intake in rats. Psychopharmacology (Berl.) 76, 30-38.

Seoane, L. M., Al-Massadi, O., Barreiro, F., Dieguez, C., and Casanueva, F. F. (2007). Growth hormone and somatostatin directly inhibit gastric ghrelin secretion. An in vitro organ culture system. J. Endocrinol. Invest. 30, RC22-RC25.

Sheriff, S., Kadeer, N., Joshi, R., Friend, L. A., James, J. H., and Balasubramaniam, A. (2012). Des-acyl ghrelin exhibits pro-anabolic and anticatabolic effects on C2C12 myotubes exposed to cytokines and reduces burn-induced muscle proteolysis in rats. Mol. Cell. Endocrinol. 351, 286-295.

Shimada, M., Date, Y., Mondal, M. S., Toshinai, K., Shimbara, T., Fukunaga, K., et al. (2003). Somatostatin suppresses ghrelin secretion from the rat stomach. Biochem. Biophys. Res. Commun. 302, 520-525.

Shimon, I., Taylor, J. E., Dong, J. Z., Bitonte, R. A., Kim, S., Morgan, B., et al. (1997). Somatostatin receptor subtype specificity in human fetal pituitary cultures. Differential role of SSTR2 and SSTR5 for growth hormone, thyroid-stimulating hormone, and prolactin regulation. J. Clin. Invest. 99, 789-798.

Shiratori, K., Watanabe, S., and Takeuchi, T. (1991). Somatostatin analog, SMS 201-995, inhibits pancreatic exocrine secretion and release of secretin and cholecystokinin in rats. Pancreas 6, 23-30.

Sibilia, V., Pagani, F., Mrak, E., Dieci, E., Tulipano, G., and Ferrucci, F. (2012). Pharmacological characterization of the ghrelin receptor mediating its inhibitory action on inflammatory pain in rats. Amino Acids 43, 17511759.

Siehler, S., Nunn, C., Hannon, J., Feuerbach, D., and Hoyer, D. (2008). Pharmacological profile of somatostatin and cortistatin receptors. Mol. Cell. Endocrinol. 286, 26-34.

Silva, A. P., Bethmann, K., Raulf, F., and Schmid, H. A. (2005). Regulation of ghrelin secretion by somatostatin analogs in rats. Eur. J. Endocrinol. 152, 887-894.

Smedh, U., Kaplan, J. M., Bjorkstrand, E., and Uvnas-Moberg, K. (1999). Dual effects of somatostatin analog octreotide on gastric emptying during and after intragastric fill. Am. J. Physiol. 277, R1291R1296.

Spary, E. J., Maqbool, A., and Batten, T. F. (2008). Expression and localisation of somatostatin receptor subtypes sst1-sst5 in areas of the rat medulla oblongata involved in autonomic regulation. J. Chem. Neuroanat. 35, 49-66.

Spier, A. D., and de Lecea, L. (2000). Cortistatin: a member of the somatostatin neuropeptide family with distinct physiological functions. Brain Res. Brain Res. Rev. 33, 228-241.

Stengel, A., Coskun, T., Goebel, M., Wang, L., Craft, L., Alsina-Fernandez, J., et al. (2010a). Central injection of the stable somatostatin analog ODT8-SST induces a somatostatin2 receptor-mediated orexigenic effect: role of neuropeptide Y and opioid signaling pathways in rats. Endocrinology 151, 4224-4235.

Stengel, A., Goebel, M., Luckey, A. Yuan, P. Q., Wang, L., and Taché, Y. (2010b). Cold ambient temperature reverses abdominal surgeryinduced delayed gastric emptying, and decreased plasma ghrelin levels in rats. Peptides 31, 2229-2235.

Stengel, A., Goebel, M., Wang, L., Rivier, J., Kobelt, P., Mönnikes, H., et al. (2010c). Activation of brain somatostatin(2) receptors stimulates feeding in mice: analysis of food intake microstructure. Physiol. Behav. 101, 614-622.

Stengel, A., Goebel, M., Wang, L., Rivier, J., Kobelt, P., Mönnikes, H., et al. (2010d). Selective central activation of somatostatin 2 receptor increases food intake, grooming behavior and rectal temperature in rats. J. Physiol. Pharmacol. 61, 399-407.

Stengel, A., Goebel, M., Wang, L., and Taché, Y. (2010e). Ghrelin, des-acyl ghrelin, and nesfatin-1 in gastric X/Alike cells: role as regulators of food intake and body weight. Peptides 31, 357-369.

Stengel, A., Goebel, M., Wang, L. Taché, Y., Sachs, G., and Lambrecht, N. W. (2010f). Differential distribution of ghrelin-O-acyltransferase (GOAT) immunoreactive cells in the mouse and rat gastric oxyntic mucosa. Biochem. Biophys. Res. Commun. 392, 67-71.

Stengel, A., Goebel-Stengel, M., Wang, L., Larauche, M., Rivier, J., and Taché, Y. (2011a). Central somatostatin receptor 1 activation reverses acute stress-related alterations of gastric, and colonic motor function in mice. Neurogastroenterol. Motil. 23, e223-e236.

Stengel, A., Goebel-Stengel, M., Wang, L., Luckey, A., Hu, E., Rivier, J., et al. (2011b). Central administration of pan-somatostatin agonist ODT8-SST prevents abdominal surgery-induced inhibition of circulating ghrelin, food intake and gastric emptying in rats. Neurogastroenterol. Motil. 23, e294e308.

Stengel, A., Goebel-Stengel, M., Wang, L., Shaikh, A., Lambrecht, N. W., Rivier, J. E., et al. (2011c). Abdominal surgery inhibits circulating acyl ghrelin, and ghrelin-O-acyltransferase levels in rats: role of the somatostatin receptor subtype 2. Am. J. Physiol. Gastrointest. Liver Physiol. 301, G239-G248.

Stengel, A., Keire, D., Goebel, M., Evilevitch, L., Wiggins, B., Taché, Y., et al. (2009). The RAPID method for blood processing yields new insight in plasma concentrations and molecular forms of circulating gut peptides. Endocrinology 150, 5113-5118.

Sternini, C., Wong, H., Wu, S. V., de Giorgio, R., Yang, M., Reeve, J. Jr., etal. (1997). Somatostatin 2A receptor is expressed by enteric neurons, and by interstitial cells of Cajal and enterochromaffin-like cells of the gastrointestinal tract. J. Comp. Neurol. 386, 396-408.

Strassburg, S., Anker, S., Castaneda, T., Burget, L., Perez-Tilve, D., Pfluger, P. T., et al. (2008). Long-term effects of ghrelin and ghrelin receptor agonists on energy balance in rats. Am. J. Physiol. Endocrinol. Metab. 295, E78-E84.

Strowski, M. Z., Parmar, R. M., Blake, A. D., and Schaeffer, J. M. (2000). Somatostatin inhibits insulin and glucagon secretion via two receptors subtypes: an in vitro study of pancreatic islets from somatostatin receptor 2 knockout mice. Endocrinology 141, 111-117.

Sun, Y., Ahmed, S., and Smith, R. G. (2003). Deletion of ghrelin impairs neither growth nor appetite. Mol. Cell. Biol. 23, 7973-7981.

Sun, Y., Wang, P., Zheng, H., and Smith, R. G. (2004). Ghrelin stimulation of growth hormone release and appetite is mediated through the growth hormone secretagogue receptor. Proc. Natl. Acad. Sci. U.S.A. 101, 4679-4684.

Suzuki, K., Jayasena, C. N., and Bloom, S. R. (2011). The gut hormones in appetite regulation. J. Obes. 2011, 528401.

Taal, B. G., and Visser, O. (2004). Epidemiology of neuroendocrine tumours. Neuroendocrinology 80 (Suppl. 1), 3-7.

Taché, Y., and Bonaz, B. (2007). Corticotropin-releasing factor receptors and stress-related alterations of gut motor function. J. Clin. Invest. 117, 33-40.

Tang-Christensen, M., Vrang, N., Ortmann, S., Bidlingmaier, M., Horvath, 
T. L., and Tschöp, M. (2004). Central administration of ghrelin and agoutirelated protein (83-132) increases food intake and decreases spontaneous locomotor activity in rats. Endocrinology 45, 4645-4652.

Tansy, M. F., Martin, J. S., Landin, W. E., and Kendall, F. M. (1979). Species difference in GI motor response to somatostatin. J. Pharm. Sci. 68, $1107-$ 1113.

Tebbe, J. J., Pasat, I. R., Mönnikes, H., Ritter, M., Kobelt, P., and Schafer, M. K. (2005). Excitatory stimulation of neurons in the arcuate nucleus initiates central CRF-dependent stimulation of colonic propulsion in rats. Brain Res. 1036, 130-138.

Thoss, V. S., Perez, J., Duc, D., and Hoyer, D. (1995). Embryonic and postnatal mRNA distribution of five somatostatin receptor subtypes in the rat brain. Neuropharmacology 34 1673-1688.

Tizabi, Y., and Calogero, A. E. (1992). Effect of various neurotransmitters and neuropeptides on the release of corticotropin-releasing hormone from the rat cortex in vitro. Synapse 10, 341-348.

Toshinai, K., Mondal, M. S., Nakazato, M., Date, Y., Murakami, N., Kojima, M., et al. (2001). Upregulation of ghrelin expression in the stomach upon fasting, insulin-induced hypoglycemia, and leptin administration. Biochem. Biophys. Res. Commun. 281, 1220-1225.

Tringali, G., Greco, M. C., Lisi, L., Pozzoli, G., and Navarra, P. (2012). Cortistatin modulates the expression and release of corticotrophin releasing hormone in rat brain. Comparison with somatostatin and octreotide. Peptides 34, 353-359.

Tschöp, M., Smiley, D. L., and Heiman, M. L. (2000). Ghrelin induces adiposity in rodents. Nature 407, 908-913.

Tschöp, M., Wawarta, R., Riepl, R. L., Friedrich, S., Bidlingmaier, M., Landgraf, R., et al. (2001a). Post-prandial decrease of circulating human ghrelin levels. J. Endocrinol. Invest. 24, RC19-RC21.

Tschöp, M., Weyer, C., Tataranni, P. A., Devanarayan, V., Ravussin, E., and Heiman, M. L. (2001b). Circulating ghrelin levels are decreased in human obesity. Diabetes 50, 707-709.

Tsolakis, A. V., Portela-Gomes, G. M., Stridsberg, M., Grimelius, L. Sundin, A., Eriksson, B. K., et al. (2004). Malignant gastric ghrelinoma with hyperghrelinemia. J. Clin. Endocrinol. Metab. 89, 3739-3744.

Uhl, G. R., Tran, V., Snyder, S. H., and Martin, J. B. (1985). Somatostatin receptors: distribution in rat central nervous system and human frontal cortex. J. Comp. Neurol. 240 288-304.

van der Hoek, J., Lamberts, S. W., and Hofland, L. J. (2010). The somatostatin receptor subtype 5 in neuroendocrine tumours. Expert Opin. Investig. Drugs 19, 385-399.

Veldhuis, J. D., Iranmanesh, A., Mielke, K., Miles, J. M., Carpenter, P. C., and Bowers, C. Y. (2006). Ghrelin potentiates growth hormone secretion driven by putative somatostatin withdrawal and resists inhibition by human corticotropin-releasing hormone. J. Clin. Endocrinol. Metab. 91, 2441-2446.

Viollet, C., Prevost, G., Maubert, E., Faivre-Bauman, A., Gardette, R., Kordon, C., et al. (1995). Molecular pharmacology of somatostatin receptors. Fundam. Clin. Pharmacol. 9, 107-113.

Viollet, C., Vaillend, C., Videau, C., Bluet-Pajot, M. T., Ungerer, A., L'Heritier, A., et al. (2000). Involvement of sst 2 somatostatin receptor in locomotor, exploratory activity and emotional reactivity in mice. Eur. J. Neurosci. 12, 3761-3770.

Volante, M., Allia, E., Gugliotta, P., Funaro, A., Broglio, F., Deghenghi, R., et al. (2002). Expression of ghrelin and of the $\mathrm{GH}$ secretagogue receptor by pancreatic islet cells and related endocrine tumors. J. Clin. Endocrinol. Metab. 87, 1300-1308.

Walsh, J. (1994). "Somatostatin," in Physiology of the Gastrointestinal Tract, ed. L. R. Johnson (New York: Raven Press), 31-48.

Wang, L., Goebel-Stengel, M., Stengel, A., Wu, S. V., Ohning, G., and Taché, Y. (2011). Comparison of CRF-immunoreactive neurons distribution in mouse and rat brains and selective induction of Fos in rat hypothalamic CRF neurons by abdominal surgery. Brain Res. 1415, 34-46.

Wren, A. M., Small, C. J., Ward, H. L., Murphy, K. G., Dakin, C. L., Taheri, S., et al. (2000). The novel hypothalamic peptide ghrelin stimulates food intake and growth hormone secretion. Endocrinology 141, 4325-4328.

Xidakis, C., Mastrodimou, N., Notas, G., Renieri, E., Kolios, G., Kouroumalis, E., etal. (2007). RT-PCR and immunocytochemistry studies support the presence of somatostatin, cortistatin and somatostatin receptor subtypes in rat Kupffer cells. Regul. Pept. 143, 76-82. Xu, G., Li, Y., An, W., Li, S., Guan, Y., Wang, N., et al. (2009). Gastric mammalian target of rapamycin signaling regulates ghrelin production and food intake. Endocrinology 150, 3637-3644.

Yakabi, K., Noguchi, M., Ohno, S., Ro, S., Onouchi, T., Ochiai, M., etal. (2011). Urocortin 1 reduces food intake and ghrelin secretion via $\mathrm{CRF}(2)$ receptors. Am. J. Physiol. Endocrinol. Metab. 301, E72-E82.

Yamazaki, M., Nakamura, K. Kobayashi, H., Matsubara, M., Hayashi, Y., Kangawa, K., et al. (2002). Regulational effect of ghrelin on growth hormone secretion from perfused rat anterior pituitary cells. J. Neuroendocrinol. 14, 156-162.
Yang, H., Wong, H., Wu, V., Walsh, J. H., and Taché, Y. (1990). Somatostatin monoclonal antibody immunoneutralization increases gastrin and gastric acid secretion in urethaneanesthetized rats. Gastroenterology 99, 659-665.

Yang, J., Brown, M. S., Liang, G., Grishin, N. V., and Goldstein, J. L. (2008). Identification of the acyltransferase that octanoylates ghrelin, an appetite-stimulating peptide hormone. Cell 132, 387-396.

Zigman, J. M., Nakano, Y., Coppari, R., Balthasar, N., Marcus, J. N., Lee, C. E., et al. (2005). Mice lacking ghrelin receptors resist the development of diet-induced obesity. J. Clin. Invest. 115, 3564-3572.

Conflict of Interest Statement: The authors declare that the research was conducted in the absence of any commercial or financial relationships that could be construed as a potential conflict of interest.

Received: 11 October 2012; paperpending published: 01 November 2012; accepted: 17 December 2012; published online: 11 January 2013.

Citation: Stengel A and Taché Y (2013) Activation of somatostatin 2 receptors in the brain and the periphery induces opposite changes in circulating ghrelin levels: functional implications. Front. Endocrin. 3:178. doi: 10.3389/fendo.2012.00178

This article was submitted to Frontiers in Neuroendocrine Science, a specialty of Frontiers in Endocrinology.

Copyright (c) 2013 Stengel and Taché. This is an open-access article distributed under the terms of the Creative Commons Attribution License, which permits use, distribution and reproduction in other forums, provided the original authors and source are credited and subject to any copyright notices concerning any thirdparty graphics etc. 